\title{
The major diseases associated with Safflower and some of the resistant sources
}

\begin{abstract}
There are several diseases reported to be associated with safflower (Carthamus tinctorius L.) from various growing areas in Iran. The fungal disease species; Alternaria alternate, A. carthani, Bremia lactuca, Cochlioblus sativus, Fusarium culmarum, F. oxysporum, Gibberella acuminate (Fusarium acuminate), G. intercans (Fusarium equiseti), Golovinomyces cichoracearum (Erysiple cichoracearum), Leveilla taurica, Macrophomina phaseolina, Nectria haematococca (Fusarium solani), Phytophthora drechsleri, Puccinia carthami, Pythium oliganderum, P. ultimum, Ramularia cynarae (R. carthami and or Cercospora carthami) Sclerotinia,sclerotiarum. Thanatephorus cucumeries (Rhizoctonia solani) and in case of wild safflower, Leveilla taurica, Puccinia carthami and Ramularia cynarae are reported so far. Also, studies on 31 species of Phytophthora only P. drechesleri, P. palmivora, P. caryptogea, P. quercina, P. cactorum, P. sparagi and P. erythroseptica showed to be pathogenic to safflower. There are phyllody symptoms which were observed in Fars and Yazd provinces showed floral virescence, phyllody and proliferation, proliferation of axillary buds along the stem and little leaf symptom most closely related to brinjal little leaf and periwinkle little leaf phytoplasmas, members of subgroup 16SrVI-C. Nineteen safflower genotypes were screening against Macrophomina phaseolina, the charcoal rot pathogen. Also, fourteen genotypes to Pythium ultimum (at temperatures 10, 15, 20, 25 and $30^{\circ} \mathrm{C}$ ). The results in both cases indicated that, the genotypes are variable in between to the said diseases.
\end{abstract}

Keywords: safflower, disease, fungi, resistant
Volume 4 Issue 4 - 2018

\author{
Mehdi Nasr Esfahani, Javad Yazdi, Talieh \\ Ostovar
}

Department of Plant Protection Research, Isfahan Agriculture and Natural Resources Research Center, Iran

Correspondence: Mehdi Nasr Esfahani, Department of Plant Protection Research, Isfahan Agriculture and Natural Resources Research Center, AREEO, Isfahan, Iran, Email mne20II@gmail.com

Received: July 21, 2017| Published: August 7, 2018

\section{Introduction}

Safflower, Carthamus tinctorius L., is an annual, broad leaf crop which belongs to the family of Compositeae. Safflower is cultivated worldwide as an oilseed or ornamental crop. In Iran, this crop is grown for its seeds to extract oil or feed home birds, and also for its flowers to use in medicine or ornamental purposes, and is being cultivated on approximately 1000 ha annually. ${ }^{1}$ Safflower (Carthamus tinctorius L.) is an oilseed crop of increasing importance in the world. This crop has been grown for its flowers for many years in Iran, which is one of the centers of safflower culture in the old world. ${ }^{2}$ In recent years due to an parts, reduced seed sizes usually occur. Disease incidence and severity are often greatest when maturing increasing demand for vegetable oil for the human uses, its production as an oilseed crop has received a great deal of attention. Growth of the crop is severely affected by many seed, soil and air borne fungal diseases such as Fusarium and Verticillium wilt, Phythophthora and stem rot, rust, and Alternaria leaf spot. They are namely as; Alternaria alternat, A. carthani, Bremia lactuca, Cochlioblus sativus, Fusarium culmarum, Foxysporum, Gibberella acuminate (Fusarium acuminate), G. intercans (Fusarium equiseti), Golovinomyces cichoracearum (Erysiple cichoracearum), Leveilla taurica, Macrophomina phaseolina, Nectria haematococca (Fusarium solani), Phytophthora drechsleri, Puccinia carthami, Pythium oliganderum, P. ultimum, Ramularia cynarae (R. carthami and or Cercospora carthami)Sclerotinia,sclerotiarum, Thanatephorus cucumeries (Rhizoctonia solani) and in case of wild safflower, Leveilla taurica, Puccinia carthami and Ramularia cynarae., ${ }^{3,4}$ Safflower plants (Carthamus tinctorius L.) with phyllody symptoms were observed by Salehi et al., ${ }^{5}$ in Fars and Yazd provinces of Iran. They reported that, affected plants show floral virescence, phyllody and proliferation, proliferation of auxiliary buds along the stem and little leaf symptoms. ${ }^{5}$ Recently, charcoal rot caused by Macrophomina phaseolina has been considered as a relatively important disease in safflower. The first report of charcoal rot disease on safflower growth in Iran was in northeastern Golestan Province in the summer of 2002. ${ }^{6}$ M. phaseolina, the causal agent of seedling blight, root rot and charcoal rot of more than 500 crop and non crop species; primarily is a soil-borne fungus. ${ }^{7}$ Although initial infections occur at the seedling stage, they remain latent until the safflower plant approaches flowering or maturity. The first symptom is general wilting of the plant during the middle of hot days followed by a recovery in the evening as temperature declines. The stems of infected plants eventually take on a gray discoloration at the base and finally, the vascular bundles may become covered with microsclerotia of the fungus. Since charcoal rot restricts the flow of water and nutrients to the upper plants are stressed by drought and high temperature which leads to premature plant death. In some cases, this pathogen kills up to $25 \%$ of the plants in commercial fields of safflower. ${ }^{8}$ Similar to other crops, management strategies to control charcoal rot in safflower including crop rotation, lower plant density and scheduling planting date and irrigation to reduce the effect of mid-season drought stress. ${ }^{7}$ Planting resistant cultivars is the most permanent and practical way for the control of the disease, because above mentioned strategies fail to provide adequate control. Although, responses of different genotypes to the charcoal rot disease caused by M. phaseolina have been reported many times in other crops such as and soybean ${ }^{9}$ and alfalfa ${ }^{10}$ such information are not available in the literature for safflower. Therefore, the objective of this study was to screen some genotypes of safflower under field conditions for resistance to charcoal rot disease. We further report those traits that are correlated to the resistance for indirect selection 
programs. Safflower suffers severely from soil pathogens, which may attack seed, germinating seed, and young. Seedlings or at time of seed formation, causing directly or indirectly yield and quality losses. Seed and seedling rots by Pythium as well as Phytophthora rots are among the more devastating soil borne diseases of safflower. ${ }^{11,12}$ Studies showed that Pythium ultimum Trow. is the causal agent of seed rot and seedling damping-off of safflower in Iran and other countries. ${ }^{12-14}$ It is not only made some limitations for safflower production in Iran, but also for the other producing areas in the world. The pathogen parasitizes seeds and invades the hypocotyl or first internode tissues of safflower seedlings and causes rotting and collapse of infected tissues and finally decays seeds and seedlings. ${ }^{15,16}$ Although different chemical fungicides are used to control damping-off, but similar to other fungi diseases the best way for decrease the losses is planting the resistant cultivars. The condition of infection, seed decay and seedling death caused by Pythium has been studied in safflower and other crop plants ${ }^{14,17-19}$ Like other soil borne pathogenic fungi, severity of infection by Pythium, incidence of damping-off and loses in crop production is a function of environmental factors and how the plants can use from their genetic potential to resist against the pathogen. ${ }^{13}$ Among the most important environmental factors which can favor the disease, temperature plays a key role. The optimum temperatures for infection of citrus fruits to brown rot that caused by Phytophthora palmivora were 27 to $30^{\circ} \mathrm{C} .{ }^{20}$ Ben-Yephet \& Nelson ${ }^{17}$ studied the effects of 20,24, 28 and $300^{\circ} \mathrm{C}$ on differential suppression of Pythium irregulare and showed that the pathogen caused damping-off in cucumber only at 20 and $240{ }^{\circ} \mathrm{C}$. Temperature had a profound impact on root rot development, plant growth and infection of carambola (Averrhoa carambola) roots by Pythium splendens. ${ }^{21}$ Infection of apples and pears with Phytophthora cactorum required 3 to $7 \mathrm{~h}$ of wetness at temperature 15 to $30{ }^{\circ} \mathrm{C} .{ }^{22}$ Pythium aphanidermatum and Pythium myriotylum are considered to be broad host range species favored by very warm conditions, whereas others such as P. ultimum and P. irreguare are considered to be broad host range species favored by cool conditions. ${ }^{23}$ The incidence of damping off of safflower caused by P. splendens was reported to increase with temperature from 10 to $250^{\circ} \mathrm{C},{ }^{14-16}$ performed an experiment on infected soil with P. ultimum and indicated that temperature level affected emergence of safflower seedlings and incidence of damping-off. They showed that safflower should be seeded early when soil temperature is low, even though emergence may be slow. Also they concluded that if seeding is delayed until soil temperatures are higher than $10^{\circ} \mathrm{C}$, growers should consider not planting safflower if soil moisture levels are high. ${ }^{14} \mathrm{On}$ the other hand the optimum temperature for safflower seed germination is about $25^{\circ} \mathrm{C} .{ }^{24}$ As noted, the effect of temperature on seed and seedling growth and incidence of Pythium damping-off in safflower has been investigated by researchers. But the best temperature for both pathogen and host has not been investigated. So, finding the optimum temperature in which favorable conditions provide to both fungal infection and expression of disease resistance in host is an important aim of safflower breeders. This study was undertaken to determine the temperature conditions decreasing seed rots and seedling damping-off caused by P. ultimum in different safflower genotypes. The objectives were to find temperature in which the lowest seed and seedling death takes place, recognize the most resistant genotype to the pathogen; and determine the effect of temperature $\times$ genotype interaction on the disease.

\section{Materials and methods}

There are several fungal diseases reported to be associated with safflower in Iran including wild ones by several workers, which are reported in due courses of time from various safflower growing areas. This has to be mentioned that, all are summarized and edited by Professor Ershad ${ }^{4}$ under " Fungi of Iran" which are given in results. Thus, simply the key reference is given over here as Ershad, ${ }^{4}$ though the main authors are also presented in the front of the reported fungi separately. And, also the fungal species, place and the name of authors are given respectively. ${ }^{4}$ Salehi et al. ${ }^{25}$ worked on the phytoplasma through transmitting it from diseased to healthy safflower by grafting and from safflower to safflower and periwinkle by dodder (Cuscuta campestris). Also, the presence of phytoplasmas in diseased plants was shown by them through direct and nested polymerase chain reaction assays using phytoplasma-specific primer pairs P1/P7 and R16F2n/ R2. Restriction fragment length polymorphism (RFLP) analysis of nested R16F2n/R2 primed PCR product (1.2kb). Nearly full length 16S rDNA sequences of 18 phytoplasmas including SP were aligned using ClustalX1.81. ${ }^{26}$ Phylogenetic tree was constructed using the neighbor joining (NJ) plot option of Clustal X. Acholeplasma laidlawii (GenBank accession No. M23932) was used as outgroup to root the tree. Bootstrapping was performed 1000 times to estimate the stability and support for the branches. The 16S rDNA sequence homology between strains was evaluated after alignments were generated by using homology matrix distance option of DNAMAN program version 4.02 (Lynon Corporation, Canada). Putative restriction site maps of $16 \mathrm{~S}$ rDNA of SP and similar phytoplasma sequences belonging to 16SrVI group were generated using Map Draw option of DNASTAR (USA) program. ${ }^{25}$ Pahlavani et al.,${ }^{27}$ worked on sources of resistance to charcoal rot disease of safflower. Nineteen safflower genotypes that originated from different geographical regions were screening for their response to infection with Macrophomina phaseolina, the charcoal rot pathogen. The plants were evaluated for length and width of necrotic lesion at the entry point of inoculum at flowering (LNF and WNF, respectively) and maturity stages (LNM and WNM, respectively), and penetration depth of necrosis in the stem (PDN). Some morphological characteristics including plant height, number of days to maturity, diameter of lower stem (DLS), diameter of vascular bundle (DVS) and relative water content of lower stems (SRWC) were also measured. ${ }^{27}$

Data evaluation and Pearson's correlation analysis among the measured traits were performed for the 19 genotypes with the SAS. ${ }^{28}$ Following the correlation analysis the relationship between diameter of lower stem (DLS) and disease related traits (LNF, WNF, LNM. WNM and PDN) were also determined by performing a regression analysis. For grouping the genotypes on the basis of resistance or susceptibility reaction to M. phaseolina infection, a cluster analysis was made with five diseases related traits including LNF, WNF, LNM, WNM and PDN. The cluster analysis was carried by using of squared Euclidean distance to construct an Unweighted Pair Group Method with Arithmetic mean (UPGMA) dendrogram according to Johnson and Wichern. The cluster analysis and plotting dendrogram were processed using SPSS software (Statistical Package for Social Sciences, Inc. Release 10.0.5, 1999). Pahlavani et al.,27 stated that, improvement of genetic potential in safflower (Carthamus tinctorius) against Pythium species would be an efficient means of control of this major seed and seedling fungal pathogen. The type and content of reaction for plant to pathogen could be severely affected by environmental conditions such as temperature. In this study by Pahlavani et al., ${ }^{27}$ seed rot and seedling damping-off of fourteen safflower genotypes that came from different origins, were 
evaluated using Pythium ultimum infected and sterile paper towels at temperatures $10,15,20,25$ and $30^{\circ} \mathrm{C}$. Both factors including the temperatures and the genotypes and their interaction affected seed germination of safflower. ${ }^{27}$ After examining data with a KolmogorovSmirnov (KS) test, data were put through a log transformation to stabilize the variance. Although data transformation decreased error in the coefficient of variation in analysis of variance table but had no significant effects on results, so the raw data were used in all analyses. Analysis of variance, least significant differences (LSD) test and KS test were carried out using the GLM procedure of SAS. ${ }^{28}$

\section{Results}

The reported fungal diseases to be associated with safflower in Iran including wild ones given as fallows. Safflower, Carthamus tinctorius L, Alternaria altenata (Fr.) Keissi.-Kennanshah, Sistan Bremia lactucae Reg. f. carthami Milovtzova - Kermanshah, Khuzestan Cochlibolus sativus (lto \& Kuribayshi) Drechsler ex Dastur (Anamorph: Bipolaris sorokiniana (Sacc.) ShocTnaker) Kennanshah. Fusarium culmorum (W.G. Sm.) Sacc. - Kemianshah F. oxysporum Schltdl. - Widespread Fusarium sp. - Dezful Gibberella acuminata Wollenw. (Anamorph: Fusarium acuminatum Ellis \& Everh.) - Kermanshah G. intricans Wollenw. (Anamorph: Fusarium equiseti (Corda) Sacc.) Kermanshah. Golovinomyces cichoracearum (DC.) V.P. Heluta = Erysiphe cichoracearum DC. DeziTil, Esfahan, Kermanshah, Leveillula taurica (Lev.) G. Arnaud =L. compositarum Golov. f. carthami Jacz. - Damavand, Esfahan, Evin, Ghazvin, Karaj, Kermanshah, Varamin. Macrophomina phaseolina (Tassi) Goid $=M$. phaseoli (Maubl.) S.F. Ashby = Tiarosporella phaseolina (Tassi) Aa Widespread Nectria haematococca (Berk. \& Broorne) Wollenw. var. brevicona (Wollenw.) Gerlach (Anamorph: Fusarium solani (Mart.) Sacc.).Widespread. Phytophthora drechsleri Tucker - Widespread Puccinia carthami (Hultz.) Corda - Azarbaijan, Esfahan, Gorgan, Iranshahr, Jiroft, Kermanshah, Khuzestan, Sari. Pythium oligandrum Drechsler - Kermanshah (P. ultimum Trow Widespread. Ramularia cynarae Sacc. $=R$. carthami Zaprom. - Kermanshah, Khnzestan, Moghan, Sari Sclerotinia sclerotiorum (Lib.) de Bary- Darab (khani, 2008). Thanatephorus cucumeris (Prank) Donk (Anamorph; Rhizoctonia solani KUhn) - Widespread (ANONYMOUS 1967a, as Rhizoctonia sp.,). Wild Safflower, Carthamus oxyacantha M. B. Leveillula taurica (Lev.) G. Amaud = L. compositarum Golov. f. carthami Jacz. - Evin, Golpaygan. Puccinia carthami (Hultz.) Corda - Ahvaz, Dezfill, Esfahan, Evin, Pars, Ghazyin, Hamedan, Jajnid, Ranun, Shiraz Ramularia cynarae Sice. $=R$. carthami Zaprom. Khuzestan.

\section{Phytoplasmas}

In the case of phytoplasma as per materials and methods, the result classified SP phytoplasma in the clover proliferation phytoplasma group (16SrVI). Sequence homology, phylogenetic and putative restriction site analyses of $16 \mathrm{~S}$ rRNA gene also identified SP phytoplasma as a member of 16SrVIgroup (Figure1). On the basis of molecular analyses, SP phytoplasma was most closely related to brinjal little leaf and periwinkle little leaf phytoplasmas, members of subgroup 16SrVI-C. The ribosomal DNA fragment amplified by nested PCR $(1.2 \mathrm{~kb})$ from SP phytoplasma and ICY positive control were separately digested with endonucleases AluI, HaeIII, HhaI, HinfI, HpaII, MseI, RsaI, Sau3AI and TaqI (Figure 2). Based on comparison with reference strains $\mathrm{s}^{29-34}$ the SP phytoplasma pattern was similar to members of CP (16SrVI) phytoplasma group. However, SP strain was distinguishable from ICY (16SrVI-A) strain by two HhaI digestion sites (Figure 2). Analysis of disease symptoms by clustering method revealed that there were four moderately resistance, ten susceptible and five moderately susceptible genotypes. However, no completely resistant genotype was found. DLS had a positive and significant correlation with all disease related traits including LNF, WNF, LNM, WNM and PDN. Therefore, this trait may be used as an index for indirect selection of resistant genotypes in safflower. The moderately resistant genotypes IUT-K115, GUA-Val6, CW-74 and AC-Stirling can be used in breeding programs to improve resistant safflower genotypes. ${ }^{27}$

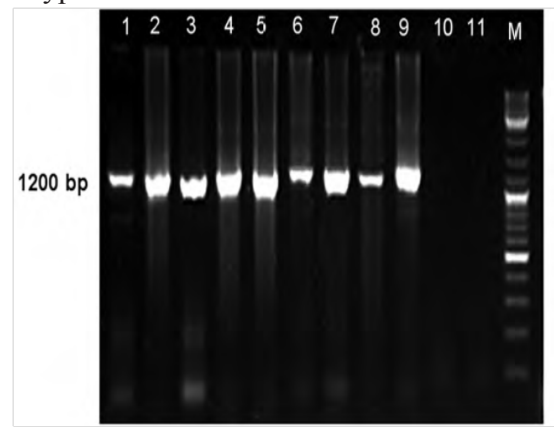

Figure I Electrophoretic pattern of $16 \mathrm{~S}$ rDNA fragment (I.2kb) amplified by nested PCR from 8 symptomatic safflower plants (Lanes I-8) and Iranian cabbage yellows phytoplasma strain (lane 9). Lanes 10-II, healthy safflower plant and water control, respectively; M, DNA ladder. ${ }^{5}$
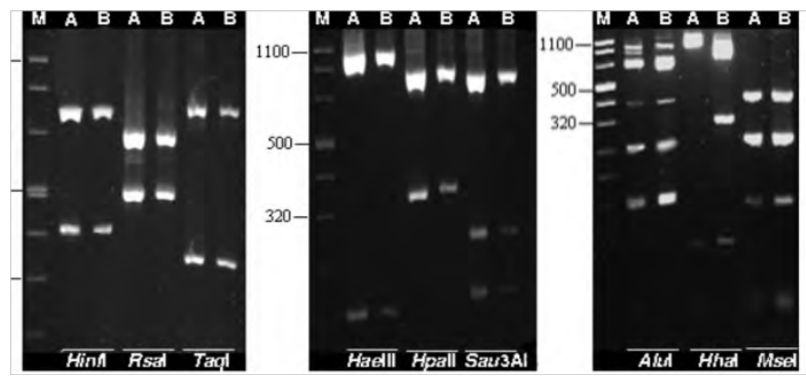

Figure 2 Restriction fragment length polymorphism (RFLP) profiles of I6S rDNA amplified by nested PCR using PI/P7 followed by RI6F2n/R2 primer pairs from safflower phyllody phytoplasma (A) and Iranian cabbage yellows phytoplasma (B). DNA products were digested with Taql, Hinfl, Sau3Al, Rsal, Alul, Hhal, Msel, Hpall and Haell and separated through a $2.5 \%$ agarose gel. Lane M, DNA ladder.5

In the case of charcoal rot disease caused by M. phaseolina in Iran, is the first work to study the reaction of safflower genotypes to this disease. The results showed considerable genetic diversity among the studied genotypes for response to infection (Table. 2). The genotypes were grouped in different clusters in relation to their resistance. These results indicate that the North American cultivars CW-74 and ACStirling as well as the Iranian breeding lines IUT-K115 and GUAVal6 were moderately resistant to charcoal rot disease. Therefore, these lines could be used as the basis of developing resistant safflower cultivars in the future (Table 3). The discovery of a moderate level of resistance to M. phaseolina in this study indicates that resistance to disease is present in current safflower germplasm sources, and this offers promise that future commercial cultivars with enhanced resistance can be developed. Reduced growth of the pathogen within host tissues that was observed by length and width of necrotic lesion at flowering and maturity stages and penetration depth of the 
necrosis. Results of this study indicated that due to the high positive and significant relationship between diameter of lower stem (DLS) and disease symptoms in the field, DLS might be a suitable trait for indirect selection among the materials to increase resistance to the charcoal rot disease in safflower (Table 3). The results showed that temperature had a significant effect on number of normal and diseased seedlings in Pythium-infected media (Table 4). Among the five different levels of treated temperatures, the lowest number of normal seedlings occurred at 25 and $30^{\circ} \mathrm{C}$, and the lowest number of diseased seedlings were also observed at 10 and $15^{\circ} \mathrm{C}$ (Table 5). There was a Considerable difference among the fourteen studied genotypes for number of normal seedlings and number of diseased seedlings in infected media under laboratory conditions. The effect of genotype $x$ temperature interaction on both number of normal seedlings and number of diseased seedlings was no significant. Cultivar CW-74 had the lowest, and cultivars LRV-51-51 and LRV-55-259 had the highest number of normal seedlings under Pythium-infected conditions. And also, Line 34072 had the lowest, and cultivar CW-74 had the highest number of diseased seedlings in Pythium-infected media. In fields infesting with P. ultimum, sowing safflower seed when temperature was more than $15^{\circ} \mathrm{C}$ is likely to have poor stand establishment due to seed rot and seedling damping-off (Table 6) 27-35 $^{27}$
Table I Pairwise homology (\%) among safflower phyllody phytoplasma and other reference phytoplasmas as determined by analysis of full length $16 \mathrm{~S}$ rDNA sequences

\begin{tabular}{llllllll}
\hline SP & BLL & PLL & CP & PWB & ICY & FM & OAY \\
\hline SP & 99.7 & 99.7 & 99.3 & 99.1 & 99.3 & 98.9 & 90.4 \\
BLL & & 99.9 & 99.5 & 99.3 & 99.2 & 99.2 & 90.7 \\
PLL & & & 99.5 & 99.2 & 99.2 & 99.1 & 90.6 \\
CP & & & & 99.7 & 99.6 & 99.5 & 91 \\
PWB & & & & & 99.4 & 99.3 & 91.2 \\
ICY & & & & & & 99.3 & 91.2 \\
FM & & & & & & & 90.8 \\
OAY & & & & & & & \\
\hline
\end{tabular}

BLL, Brinjal little leaf (X8343I); CP, Clover proliferation (Ca, Phytoplasma trifolii) (AY39026I); FM, Fragaria multicipita (AF5008I8); ICY, Iranian cabbage yellows (EF592606); OAY,Oenothera aster yellows (Ca. Phytoplasma asteris) (M30790); PLL, periwinkle little leaf (AF228053); PWB, Potato witches'-broom (AY500818); SP, Safflower phyllody (AY5008I8).5 (Ca. Phytoplasma asteris ) (M30790); PLL, periwinkle little leaf (AF228053); PWB, Potato witches'-broom (AY5008I8); SP, Safflower phyllody (AY5008I8). ${ }^{5}$

Table 2 Origin of germplasm and size of lesions caused by M. phaseolina and some morphological characteristics of 19 safflower genotypes ${ }^{27}$

\begin{tabular}{|c|c|c|c|c|c|c|c|c|c|c|c|}
\hline Genotype & Origin & $\begin{array}{l}\text { LNF } \\
(\mathrm{cm})\end{array}$ & $\begin{array}{l}\text { WNF } \\
(\mathrm{cm})\end{array}$ & $\begin{array}{l}\text { LNM } \\
(\mathrm{cm})\end{array}$ & $\begin{array}{l}\text { WNM } \\
(\mathrm{cm})\end{array}$ & PDN (\%) & $\begin{array}{l}\text { DLS } \\
(\mathrm{mm})\end{array}$ & $\begin{array}{l}\text { DVS } \\
(\mathrm{mm})\end{array}$ & $\begin{array}{l}\text { Height } \\
\text { (cm) }\end{array}$ & $\begin{array}{l}\text { Days to } \\
\text { maturity }\end{array}$ & $\begin{array}{l}\text { SRWC } \\
(\%)\end{array}$ \\
\hline Arak-28II & Iran & $2.2 \pm 0.50$ & $1.9 \pm 0.40$ & $6.7 \pm 1.12$ & $2.7 \pm 0.08$ & $38.9 \pm 5.94$ & $8.5 \pm 0.42$ & $2.1 \pm 0.13$ & $101.9 \pm 1.65$ & 99 & 57.2 \\
\hline Isfahan & Iran & $6.7 \pm 0.79$ & $4.0 \pm 0.07$ & $12.7 \pm 0.53$ & $4.1 \pm 0.14$ & $40.7 \pm 3.36$ & $10.6 \pm .23$ & $2.6 \pm 0.17$ & $116.0 \pm 1.09$ & 100 & 57.8 \\
\hline LRV-55295 & Iran & $6.0 \pm 0.44$ & $3.9 \pm 0.00$ & $6.3 \pm 0.65$ & $3.9 \pm 0.40$ & $32.6 \pm 4.10$ & $9.9 \pm 0.33$ & $2.2 \pm 0.17$ & $103.2 \pm 1.10$ & 99 & 61.6 \\
\hline IL-III & Iran & $3.6 \pm 0.34$ & $2.6 \pm 0.48$ & $8.5 \pm 0.34$ & $3.0 \pm 0.41$ & $29.9 \pm 4.25$ & $8.8 \pm 0.48$ & $1.5 \pm 0.10$ & $92.1 \pm 0.62$ & 87 & 49.4 \\
\hline GUA-I0I & Iran & $3.5 \pm 1.01$ & $3.4 \pm 0.37$ & $8.7 I \pm 0.97$ & $3.6 \pm 0.58$ & $42.9 \pm 7.21$ & $9.5 \pm 0.87$ & $1.7 \pm 0.15$ & $92.5 \pm 2.01$ & 95 & 58.4 \\
\hline GUA-Val6 & Iran & $3.4 \pm 0.89$ & $3.4 \pm 0.4 \mathrm{I}$ & $3.3 \pm 0.78$ & $3.6 \pm 0.12$ & $12.9 \pm 4.79$ & $8.9 \pm 0.23$ & $1.8 \pm 0.14$ & $100.5 \pm 0.95$ & 101 & 59.6 \\
\hline IUT-M2I & Iran & $3.4 \pm 0.65$ & $2.9 \pm 0.43$ & $13.9 \pm 1.22$ & $3.2 \pm 0.31$ & $50.1 \pm 8.29$ & $10.2 \pm 0.26$ & $1.6 \pm 0.09$ & $100.7 \pm 1.76$ & 101 & 57.6 \\
\hline IUT-K23 & Iran & $3.9 \pm 0.70$ & $3.7 \pm 0.24$ & $|3.7 \pm 1.0|$ & $3.9 \pm 0.09$ & $58.0 \pm 6.34$ & $10.1 \pm 0.67$ & $1.5 \pm 0.11$ & $98.2 \pm 1.35$ & 105 & 58.4 \\
\hline IUT-KIII & Iran & $5.7 \pm 0.54$ & $3.0 \pm 0.14$ & $10.2 \pm 0.90$ & $3.6 \pm 0.39$ & $5.3 \pm 1.00$ & $9.3 \pm 0.44$ & $1.8 \pm 0.11$ & $82.3 \pm 1.46$ & 115 & 66.5 \\
\hline Miandoab & Iran & $3.2 \pm 0.73$ & $2.0 \pm 0.31$ & $6.4 \pm 0.71$ & $4.0 \pm 00.0$ & $51.1 \pm 9.97$ & $8.9 \pm 0.31$ & $2.4 \pm 0.24$ & $93.6 \pm 1.32$ & 101 & 60.2 \\
\hline Lesaf & Canada & $5.5 \pm 0.75$ & $3.6 \pm 0.30$ & $14.5 \pm 1.24$ & $3.6 \pm 0.20$ & $44.4 \pm 6.69$ & $10.4 \pm 0.07$ & $2.0 \pm 0.13$ & $97.9 \pm 0.76$ & 99 & 5901 \\
\hline AC-Stirling & Canada & $3.9 \pm 0.73$ & $2.8 \pm 0.30$ & $7.1 \pm 1.14$ & $2.5 \pm 0.46$ & $2.9 \pm 0.36$ & $8.2 \pm 0.37$ & $1.4 \pm 0.07$ & $70.8 \pm 1.81$ & 96 & 49.2 \\
\hline Hartman & USA & $6.5 \pm 0.34$ & $3.6 \pm 0.10$ & $8.9 \pm 1.16$ & $3.7 \pm 0.18$ & $34.9 \pm 5.31$ & $10.4 \pm 0.11$ & $2.1 \pm 0.10$ & $101.8 \pm 0 / 75$ & 98 & 54.9 \\
\hline CW-74 & USA & $5.5 \pm 0.74$ & $3.6 \pm 0.30$ & $8.8 \pm 0.94$ & $3.7 \pm 0.38$ & $9.8 \pm 2.97$ & $9.8 \pm 0.52$ & $1.7 \pm 0.1 \mathrm{I}$ & $71.4 \pm 0.55$ & 94 & 50.1 \\
\hline Syrian & Syria & $6.6 \pm 0.60$ & $3.6 \pm 0.20$ & $11.2 \pm 0.90$ & $3.7 \pm 0.18$ & $35.6 \pm 6.30$ & $10.0 \pm 0.28$ & $1.9 \pm 0.13$ & $119.3 \pm 2.10$ & 129 & 58 \\
\hline PI-34070 & Un known & $4.5 \pm 0.71$ & $3.9 \pm 0.14$ & $13.6 \pm 0.69$ & $4.0 \pm 0.00$ & $32.4 \pm 4.87$ & $10.0 \pm 0.18$ & $1.9 \pm 0.10$ & $106.1 \pm 1.12$ & 98 & 53.1 \\
\hline PI-250537 & Un known & $6.4 \pm 0.40$ & $3.1 \pm 0.12$ & $7.8 \pm 0.49$ & $3.3 \pm 0.18$ & $51.2 \pm 4.46$ & $10.4 \pm 0.17$ & $2.0 \pm 0.14$ & $95.2 \pm 0.78$ & 96 & 54.5 \\
\hline PI-I99877 & Un known & $4.5 \pm 1.04$ & $3.1 \pm 0.46$ & $11.9 \pm 0.84$ & $4.0 \pm 0.00$ & $26.1 \pm 5.30$ & $10.1 \pm 0.25$ & $1.7 \pm 0.15$ & $|07.5 \pm 0.9|$ & 100 & 60.7 \\
\hline PI-I 98290 & Un known & $5.2 \pm 0.67$ & $3.3 \pm 0.36$ & $13.4 \pm 1.13$ & $4.0 \pm 0.00$ & $53.4 \pm 5.22$ & $10.1 \pm 1.37$ & $2.2 \pm 0.14$ & $105.9 \pm 2.35$ & 95 & 50.7 \\
\hline Mean & - & 4.7 & 3.2 & 9.8 & 3.6 & 34.4 & 9.7 & 1.89 & 97.7 & 100.4 & 56.7 \\
\hline
\end{tabular}


Table 3 Coefficient of Pearson correlation among disease related traits and morphological characteristic of 19 safflower genotypes

\begin{tabular}{|c|c|c|c|c|c|c|c|c|c|}
\hline Traist & LNF (cm) & WNF (cm) & LNM (cm) & WNM (cm) & PDN (\%) & DLS (mm) & $\begin{array}{l}\text { DVS } \\
(\mathrm{mm})\end{array}$ & $\begin{array}{l}\text { Height } \\
\text { (cm) }\end{array}$ & Maturity \\
\hline WNF(cm) & 0.27 & & & & & & & & \\
\hline LNM(cm) & $0.66 * *$ & 0.39 & & & & & & & \\
\hline WNM(cm) & 0.43 & 0.42 & $0.56 * *$ & & & & & & \\
\hline PDN(\%) & -0.03 & $0.46 * *$ & -0.01 & 0.29 & & & & & \\
\hline DLS(mm) & $0.68^{* *}$ & $0.7 \mid * *$ & $0.70 * *$ & $0.64 * *$ & 0.48 & & & & \\
\hline DVS(mm) & 0.33 & 0.03 & 0.08 & $0.49 * *$ & 0.37 & 0.31 & & & \\
\hline Height(cm) & 0.24 & 0.4 & 0.3 & $0.47^{*}$ & $0.53^{* *}$ & $0.52^{*}$ & $0.15^{*}$ & & \\
\hline Maturity & 0.32 & 0.17 & 0.14 & 0.22 & -0.06 & 0.13 & 0.06 & 0.35 & \\
\hline SPWC & 0.05 & 0.03 & 0.04 & 0.35 & 0.04 & 0.13 & 0.27 & 0.27 & $0.45^{* *}$ \\
\hline
\end{tabular}

* and **: Significant at 5 and I \% probability level, respectively.

Table 4 Analysis of variance of the effect of temperature and genotype on number of germinated (NGS), number of normal seedlings (NNS) and number of diseased seedlings (NDS) in infected media with Pythium ultimum in Safflower

\begin{tabular}{|c|c|c|c|c|c|c|}
\hline SV & df & NGS & SV & df & NNS & NDS \\
\hline Temperature(T) & 4 & $49.51 * *$ & Temperature(T) & 4 & $4856.96 * *$ & $366.04 * *$ \\
\hline Error I & 15 & 9.69 & Genotype (G) & 13 & 78.38 & 40.89 \\
\hline Media (M) & I & $75.78 * *$ & $\mathrm{G} \times \mathrm{T}$ & 52 & 39.2 & 48.02 \\
\hline$M \times T$ & 4 & 5.54 & Error & 210 & 63.27 & 57.27 \\
\hline Error 2 & 15 & 6.82 & Total & 279 & - & - \\
\hline Genotype (G) & 13 & $65.37 * *$ & & & & \\
\hline $\mathrm{G} \times \mathrm{T}$ & 52 & $10.60 * *$ & & & & \\
\hline$G \times M$ & 13 & 6.48 & & & & \\
\hline$G \times M \times T$ & 52 & 4.17 & & & & \\
\hline Error 3 & 390 & 6.01 & & & & \\
\hline Total & 559 & & & & & \\
\hline
\end{tabular}

** Significant at \% level.

Table 5 Effect of temperature and Pythium- infection on seed germination, number of normal and diseased seedlings in safflower.

\begin{tabular}{llllll}
\hline Temperature(C) & NGC & NNS & NDS & Media & NGS \\
10 & $45.4 \pm 2.59$ & $25.7 \pm 4.91$ & $19.7 \pm 4.81$ & Sterile & $45.6 \pm 2.78$ \\
15 & $44.7 \pm 2.76$ & $27.5 \pm 6.37$ & $17.2 \pm 5.69$ & Infected & $44.9 \pm 2.91$ \\
20 & $45.8 \pm 2.37$ & $25.2 \pm 11.31$ & $20.5 \pm 10.32$ & LSD $(0.05)$ & $0.47 \mid$ \\
25 & $44.9 \pm 2.79$ & $9.0 \pm 6.17$ & $34.9 \pm 6.84$ & & \\
30 & $43.6 \pm 3.43$ & $9.5 \pm 8.14$ & $33.3 \pm 8.05$ & & \\
$\operatorname{LSD}(0.05)$ & 0.888 & 2.963 & 2.819 & & \\
\hline
\end{tabular}

Means followed by the same letter within a column are not significantly different ( $P>0.05)$ according to the least significant difference (LSD) test; NGS, number of germinated seeds; NNS, number of normal seedlings; NDS, number of diseased seedlings. 
Table 6 Effect of safflower genotype on seed germination, number of normal and diseased seedlings in infected media with Pythium ultimum at temperatures $10,15,20,25$ and $30^{\circ} \mathrm{C}$

\begin{tabular}{|c|c|c|c|c|c|c|c|c|}
\hline \multicolumn{9}{|l|}{ NGS } \\
\hline Genotype & Origin & $10^{\circ} \mathrm{C}$ & $15^{\circ} \mathrm{C}$ & $20^{\circ} \mathrm{C}$ & $25^{\circ} \mathrm{C}$ & $30^{\circ} \mathrm{C}$ & NNS & NDS \\
\hline Arak-28II & Iran & $46.1 \pm 2.87$ & $46.5 \pm 3.59$ & $46.2 \pm 1.91$ & $47.3 \pm 2.62$ & $47.8 \pm 0.81$ & $20.3 \pm|2.2|$ & $26.0 \pm 11.56$ \\
\hline Isfahan & Iran & $45.6 \pm 1.41$ & $43.6 \pm 2.08$ & $46.1 \pm 0.81$ & $45.0 \pm 3.69$ & $43.6 \pm 2.62$ & $|8.8 \pm||.0|$ & $25.5 \pm 8.87$ \\
\hline Zarghan-259 & Iran & $45.5 \pm 2.70$ & $46.3 \pm 2.68$ & $45.5 \pm 1.70$ & $47.0 \pm 2.38$ & $45.8 \pm 3.68$ & $20.3 \pm 11.75$ & $25.0 \pm 9.04$ \\
\hline LRV-5I-5I & Iran & $45.5 \pm 4.76$ & $46.2 \pm 2.44$ & $45.5 \pm 2.62$ & $46.3 \pm 3.50$ & $45.7 \pm 2.75$ & $22.2 \pm 9.21$ & $23.3 \pm 7.86$ \\
\hline LRV-55-295 & Iran & $45.5 \pm 1.73$ & $46.8 \pm 2.51$ & $45.5 \pm 1.82$ & $46.3 \pm 2.38$ & $45.6 \pm 4.08$ & $21.8 \pm 10.79$ & $23.7 \pm 10.27$ \\
\hline IL-III & Iran & $45.8 \pm 2.50$ & $44.1 \pm 0.95$ & $44.7 \pm 1.91$ & $43.1 \pm 3.86$ & $41.8 \pm 1.73$ & $18.8 \pm 11.39$ & $25.6 \pm 9.00$ \\
\hline Dinger & Turkey & $46.6 \pm 2.62$ & $45.3 \pm 2.06$ & $45.8 \pm 1.29$ & $45.3 \pm 1.70$ & $46.0 \pm 2.62$ & $19.8 \pm 11.50$ & $25.4 \pm 11.94$ \\
\hline Syrian & Syria & $46.7 \pm 2.21$ & $44 . I \pm I .4 I$ & $45.0 \pm I .4 I$ & $45.0 \pm 1.50$ & $43.7 \pm 0.95$ & $20.6 \pm 12.72$ & $24.5 \pm 11.94$ \\
\hline CW-74 & USA & $45.7 \pm 3.46$ & $42.0 \pm 3.20$ & $45.1 \pm 3.69$ & $45.0 \pm 0.95$ & $43.8 \pm 2.44$ & $|4.9 \pm| \mid .53$ & $27.7 \pm 11.93$ \\
\hline Hartman & USA & $47.7 \pm 1.70$ & $47.6 \pm 0.81$ & $47.7 \pm 2.06$ & $47.7 \pm 1.50$ & $47.2 \pm 0.57$ & $20.4 \pm 10.53$ & $26.6 \pm 10.53$ \\
\hline Aceteria & Canada & $45.3 \pm 1.70$ & $46.8 \pm 2.38$ & $47.2 \pm 4.69$ & $45.3 \pm 1.15$ & $44.5 \pm 1.50$ & $18.1 \pm 12.75$ & $26.6 \pm 13.40$ \\
\hline PI-250537 & Unknown & $46.8 \pm 2.51$ & $44.7 \pm 2.61$ & $47.2 \pm 2.36$ & $44.8 \pm 2.94$ & $42.6 \pm 2.50$ & $19.5 \pm 10.80$ & $24.0 \pm 10.42$ \\
\hline $5-54 I$ & Unknown & $45.5 \pm 3.30$ & $44.1 \pm 1.73$ & $44.2 \pm 3.69$ & $41.5 \pm 1.29$ & $39.1 \pm 1.73$ & $16.2 \pm 11.10$ & $25.2 \pm 10.99$ \\
\hline 34074 & Unknown & $43.5 \pm 2.06$ & $43.5 \pm 1.91$ & $45.7 \pm 3.68$ & $43.5 \pm 3.59$ & $4 I .3 \pm 2.06 \mathrm{I}$ & $19.3 \pm 12.16$ & $22.3 \pm 10.25$ \\
\hline LSD & - & 2.283 & 2.39 & 2.534 & 2.377 & 2.653 & - & - \\
\hline
\end{tabular}

Means followed by the same letter within a column are not significantly different $(P>0.05)$ according to the least significant difference (LSD) test; NGS, number of germinated seeds; NNS, number of normal seedlings; NDS, number of diseased seedling ${ }^{35}$

\section{Discussion}

The reported fungi on safflower in Iran indicating that, there are several fungi infecting this crop with almost similar reported fungi from other places of the world. Salehi et al., ${ }^{5}$ based on disease symptoms, graft and dodder transmission and positive PCR reaction with universal phytoplasma primers proved that the Iranian SP agent is a phytoplasmal nature. RFLP analysis of PCR products amplified by the primer pair R16F2n/R2, sequence homology, putative restriction site and phylogenetic analyses of $16 \mathrm{~S}$ rDNA indicated that SP is closely related to members of clover proliferation, $16 \mathrm{SrVI}$ group. Results of these analyses suggest classification of SP in the 16SrVI-C ribosomal subgroup, distinct from CP, PWB and ICY (16SrVI-A), ${ }^{25-34}$ FM (16SrVI-B), ${ }^{34}$ and very close to BLL and PLL (16SrVI-C) $)^{34-36}$ strains. Previous investigations using various endonucleases, showed that phytoplasma members of the clover proliferation subgroup could be differentiated from each other by AluI, HhaI and MseI enzymes ${ }^{28-34}$ in agreement with the results of RFLP analyses (Figure 1 \& 2) of our study. According to restriction-site analysis of PCR-amplified $16 \mathrm{~S} \mathrm{rDNA}^{37}$ and phylogeneticanalysis of $16 \mathrm{~S} \mathrm{rDNA},{ }^{38}$ the safflower phyllody phytoplasma from Israel is caused by an agent belonging to $16 \mathrm{SrI}$-Bs subgroup, vectored by Neoaliturus fenestratus, ${ }^{39,40} \mathrm{a}$ leafhopper found also in safflower fields in Zarghan, Iran. However, the ability of N. fenestratus to transmit the Iranian SP agent is yet to be tested. To our knowledge safflower is reported for the first time as a host of CP phytoplasma group. ${ }^{5}$ Pahlavani et al., ${ }^{27}$ stated that, this is the first work to study the reaction of safflower genotypes to charcoal rot disease caused by M. phaseolina in Iran. Their results showed considerable genetic diversity among the studied genotypes for response to infection. The genotypes were grouped in different clusters in relation to their resistance. These results indicate that the North American cultivars CW-74 and AC-Stirling as well as the Iranian breeding lines IUT-K115 and GUAVal6 were moderately resistant to charcoal rot disease. Therefore, these lines could be used as the basis of developing resistant safflower cultivars in the future. The discovery of a moderate level of resistance to M. phaseolina in this study indicates that resistance to disease is present in current safflower germplasm sources, and this offers promise that future commercial cultivars with enhanced resistance can be developed. Resistance to M. phaseolina in safflower may be associated with resistance to drought stress as reported in grain sorghum and soybean (Pratt et al., 1998). Although response to drought stress and also seed yield of the genotypes were not investigated in this study, CW- 74 and AC-Stirling that had high yield and other suitable agronomic characters, and have been released for cultivation in rain fed area. ${ }^{41}$ So these genotypes can be used for the crossing with Iranian genotypes to develop charcoal rot resistant genotypes. For better understanding of resistance in safflower genotypes to M. phaseolina, it is recommended that level of stress-related free amino acids to be measured in the next studies. Reduced growth of the pathogen within host tissues that was observed by length and width of necrotic lesion at flowering and maturity stages and penetration depth of the necrosis may be due to lower levels of the stress-related free amino acids praline and asparagines in resistant genotypes than susceptible genotypes as reported in soybean..$^{42}$ Since field study of plant reaction to the pathogen is difficult and time consuming, breeders often search for easily and rapidly evaluated traits that are correlated to resistance. Results of this study indicated that due to the high positive and significant relationship between diameter of lower stem (DLS) and disease symptoms in the field, DLS might be a suitable trait for indirect selection among the materials to increase resistance to the charcoal rot disease in safflower. Therefore, this trait could be used as a selection index for improving resistant 
and/or tolerant genotypes to the charcoal rot pathogen in safflower. ${ }^{27}$

Both temperature and genotype affected number of germanizing damages of the P. ultimum. Some of the studied genotypes had good potential of normal seedlings in Pythium-infected media and could be considered in breeding program for improvement of resistance to Pythium damping-off in safflower. The number of diseased seedlings (NDS) caused by P. ultimum increased as incubation temperatures increased over $15^{\circ} \mathrm{C}$ and reached a maximum at 25 and $30^{\circ} \mathrm{C}$ (Figure 2). And, the maximum number of normal seedlings (NNS) were observed at $15^{\circ} \mathrm{C}$ and decreased as temperature increased up to $30^{\circ} \mathrm{C}$ (Figure 2). The increase in incidence of damping-off with temperature observed is in accordance with results of Thomas et al. ${ }^{19}$ on Pythium splendens, and $24^{\circ} \mathrm{C}$ is reported to be optimal for $\mathrm{P}$ irregular. ${ }^{17}$ Mundel et al. ${ }^{14}$ evaluated the effects of soil temperature, soil moisture and P. ultimum infection on the emergence of 12 safflower genotypes. They found that emergence in Pythium-infested soil was relatively high at 5,10 and $15^{\circ} \mathrm{C}$, but was dramatically lower at 20 and $25^{\circ} \mathrm{C}$, particularly in soils with a moisture level of $30 \mathrm{kpa}$. They also observed post-emergence damping-off of seedlings in Pythium- infested soil, after maximum emergence at 15, 20 and $25^{\circ} \mathrm{C}$. The results of this study agree with the above findings. The favorability of higher temperatures on damping-off of cucumber caused by P. irregulare was also showed by Ben Yephet \& Nelson. ${ }^{17}$ Contrary to the observations of Martin \& Loper ${ }^{43}$ and Ploetz ${ }^{21}$ showing Pythium infection occurs mainly at lower temperatures, we observed an increase in disease incidence with temperature. This discrepancy may be due to differences between isolates, since isolates of the same Pythium species vary in their optimum temperature. ${ }^{17}$ The observation of Lifshitz \& Hancock ${ }^{44}$ offer another possible explanation. They found that the optimum temperature for Pythium growth shifted to lower temperature when the fungus was added to non sterile instead of sterile soil, indicating a difference between the physiological and ecological optima. The results of this study indicate that to reduce the severity of damping-off in fields infested with the Pythium pathogen, safflower should be seeded early when soil temperature is low, even though germination may be slow or lower. In Golestan area, the mean temperature in March and April is 10.6 and $16.0^{\circ} \mathrm{C}$, respectively. In the absence of major seedling diseases, mid-March to mid-April has been identified as optimum planting period for safflower in this area. If seeding is delayed until soil temperatures are higher than $15^{\circ} \mathrm{C}$, safflower growers should consider not planting safflower if other conditions are favorable. Other studies with Pythium spp. have indicated that high soil temperature favours the development of seed and root rots ${ }^{16,17}$ and it may be easier to manipulate seeding date than to eliminate the pathogen. This study confirms these observations for P. ultimum, which is widespread in almost all fields and is the main inciter of damping-off ofsafflower in Iran. ${ }^{13}$ Van der Plaats Niterink ${ }^{23}$ in her monograph on Pythium noted that the role of Pythium spp. often dependon external factors. "When conditions are favorable for the fungus but less for the host, Pythium species can become very pathogenic". In the interaction that is described in this paper, P. ultimum appears to be an opportunist in that it causes its greatest damage on safflower not under temperature conditions that are most favorable for it, but when the host genotype is susceptible. From the study of Pahlevani et al., ${ }^{35}$ it can be concluded that temperature and genotype conditions play a major role in P. ultimum damping off of safflower. Therefore, implementation of proper sowing time as mentioned above and selection of less susceptible safflower cultivars should be part of Pythium management practices to reduce damping-off incidence and severity under field cultivation. Therefore, it is advisable to plant Safflower early when soil temperature is cool. ${ }^{35}$

\section{Acknowledgements}

None.

\section{Conflict of interest}

Author declares that there is no conflict of interest.

\section{References}

1. FAO. FAO database collection; 2008.

2. Knowels PF. Centers of plant diversity and conservation of crop germplasm; Safflower. Econ Bot. 1969;23:324-329.

3. L Dajue, HH Mundel. Safflower, Carthamus tinctorius. Italy: L IPGRI; $1996 ; 83$.

4. D Ershad. Fungi of Iran Ministry of Jihad-e- Agriculture. Agricultural Research, Education and Extention Organization. 2009:535.

5. M Salehi, K Izadpanah, M Siampour, et al. Molecular characterization and transmission of safflower phyllody phytoplasma in iran. J Plant Pathol. 2009;91(2):453-458.

6. Razavi SE, Pahlavani MH. Isolation of the causal of charcoal rot disease of safflower and resistance of some cultivars to the disease. $16^{\text {th }}$ Iranian Plant Protection Congress. Iran: SAS; 2004.

7. Smith GS, Carvil ON. Field screening of commercial and experimental soybean cultivars for their reaction to Macrophomina phaseolina. Plant Dis. 1997;81:363-368.

8. Govindappa M, Lokesh S, Rai VR. A new stem splitting symptom in safflower caused by Macrophomina phaseolina. J Phytopathology. 2005;153(9):560-561.

9. Pearson CAS, Schwenk FW, Crowe FJ, et al. Coloniziation of soybean roots by Macrophomina phaseolina. Plant Dis. 1984;68(12):10861088 .

10. Pratt RG, McLaughlin MR, Pederson GA, et al. Pathogenicity of Macrophomina phaseolina to mature plant tissues of alfalfa and white clover. Plant Dis. 1998;82:1033-1038.

11. AD. Heritage, Harrigan EKS. Environmental factors influencing safflower screening for resistance to Phytophthora cryptogea. Plant Dis. 1984;68:767-769

12. Huang HC, Morrison RJ, Mundel HH, et al. Pythium sp. "group G", a form of Pythium ultimum causing damping-off of safflower. Can J Plant Pathology. 1992;14:229-232.

13. Ahmadi MH, Pahlavani SE, Razavi. Evaluation of safflower dampingoff (Pythium ultimum). Elect J Crop Prod. 2008;1:1-16.

14. Mundel HH, Huang HC, Kozub GC, et al. Effect of soil moisture and temperature on seedling emergence and incidence of Pythium damping-off in safflower (Carthamus tinctorius L.). Can J Plant Sci. 1995;75(2):505-509.

15. Kolte SJ. Diseases of annual edible oilseed crops volume III sunflower, safflower, and nigerseed diseases. CRC Press. 1985;3:118,

16. Thomas CA. Effect of seedling age on Pythium root rot of safflower. Plant Dis Rep. 1970;54:1010-1011.

17. Ben Yephet Y, Nelson EB. Differential suppression of damping off caused by Pythium aphanidermatum, Pythium irregulare and Pythium myriotylum in compost at different temperatures. Plant Dis. 1999;83:356-360.

18. Fortnum BA, JW Rideout, SB Martin et al. Nutrient Solution Temperature Affects Pythium Root Rot in Greenhouse Float Systems. Plant Diseases. 2000;84(3):289-294.

19. Thomas CA. Effect of temperature on Pythium root rot of safflower. Plant Dis Rep. 1970;54:300. 
20. Timmer LW, Zitko SE, Gottwald TR, et al. Phytophthora brown rot of citrus: Temperature and moisture effects on infection, sporangium production, and dispersal. Plant Dis. 2000;84(2):157-163.

21. Ploetz RC. Influence of temperature on Pythium splendens induced root disease on carambola, Averrhoa carambola. Mycopathologia. 2004;157(2):225-231.

22. Grove GG, Madden LV, Ellis MA. Influence of temperature and wetness duration on sporulation of Phytophthora cactorum. Phytopathology. 1985;75:700-703.

23. Van der Plaats Niterink J. Monograph of the genus Pythium. Studies in mycology No 21. Gams W, Jacobs RPWM, editors. Netherland; 1981.

24. $\mathrm{Gu} \mathrm{ZH}, \mathrm{Xu} \mathrm{BM}$. Studies on the germination physiology and vigor of safflower seeds. Acta Phytophysiol Sinica. 1984;10:305-314.

25. Salehi M, Izadpanah K, Siampour M. Characterization of a phytoplasma associated with cabbage yellows in Iran. Plant Disease 2007;91: 625-630.

26. Thompson JD, Higgins DG, Gibson TJ. Clustal W: Improving the sensitivity of progressive multiple sequence alignment through sequence weighing, position specific gap penalties and weight matrix choice. Nucleic Acids Research. 1994;22(2):4673-4680.

27. Pahlavani MH, Razavib SE, Mirizadeha I,et al. Field screening of safflower genotypes for resistance to charcoal rot disease. Int J Plant Production. 2007;1(1):45-52.

28. SAS Institute . SAS/STAT9.1. User's guide. SAS Inst., Cary, NC. 2004.

29. Lee IM, Gundersen Rindal DE, Bartozyk IM. Revised classification scheme of phytoplasmas based on RFLP analysis of 16S rRNA and ribosomal protein gene sequences. Int J Systematic Bacteriol. 1998;48:1153-1169.

30. Wang K, Hiruki C, Chen MH. Identification of a phytoplasma causing yellows of monarda. Plant Pathol. 1998;47(1):103-106.

31. Davis RE, Dally EL. Revised subgroup classification of group $16 \mathrm{SrV}$ phytoplasmas and placement of flavescence dorée-associated phytoplasmas in two distinct subgroups", Plant Dis. 2001;85:790-797.

32. Wang K, Hiruki C. Use of heteroduplex mobility assay for identification and differentiation of phytoplasmas in the aster yellows group and the clover proliferation group," Phytopathology.
2001;91(6):546-552.

33. Jacobs KA, Lee IM, Griffiths HM, et al. A New Member of the Clover Proliferation Phytoplasma Group (16SrVI) Associated with Elm Yellows in Illinois. Plant Disease. 2003;87(3):241-246.

34. Hiruki C, Wang K. Clover proliferation phytoplasma: Candidatus Phytoplasma trifolii. Int J Syst Evol Microbiol. 2004;54(4):1349-1353.

35. Pahlavani MH, Razavi SE, Kavusi F, et al. Influence of temperature and genotype on Pythium damping-off in safflower. J Plant Breed Crop Sci. 2009;1(1):001-007.

36. Siddique ABM, Agrawal GK, Alam N, et al. Electron microscopy and molecular characterization of phytoplasmas associated with little leaf disease of brinjal (Solanum melongena L.) and periwinkle (Catharanthus roseus) in Bangladesh. J Phytopathology. 2001;149(5):237-244.

37. Schneider B, Ahrens U, Kirkpatrick BC, et al. Classification of mycoplasma-like organisms using restriction site analysis of PCRamplified 16S rDNA. J General Microbiol. 1993;139:519-527.

38. Lee IM, Gundersen Rindal DE, Davis KD, et al. Candidatus Phytoplasma asteris, a novel phytoplasma taxon associated with aster yellows and related diseases. Int J Systematic Evolutionary Microbiology. 2004;54(4):1037-1048.

39. Raccah B, Klein M. Transmission of safflower phyllody mollicute by neoaliturus fenestratus. Phytopathology. 1982;72:230-232.

40. Weintraub P, Bealand A. Insect vectors of phytoplasmas. Annu Rev of Entomol. 2006;51:91-111.

41. Mundel HH, Morrison RJ, Huang HC, et al. Registration of 'AC Stirling' safflower. Crop Sci. 1993;33(1):201.

42. Pearson CAS, Leslie JF, Schwenk FW. Nitrogen source utilization by chlorate-resistant and chloratesensitive isolates of Macrophomina phaseolina. Trans British Mycol Soc. 1987;88(4):47-52.

43. Martin FN, Loper JE. Soilborne disease caused by Pythium spp.: Ecology, epidemiology and prospects for biological control. Crit Rev Plant Sci. 1999;18(2):111-181.

44. Lifshitz R, Hancock JG. Saprophytic development of Pythium ultimum in soil as a function of water matric potential and temperature. Phytopathology. 1983;73:257-261. 